\title{
XII Conference on Transport Engineering, CIT 2016, 7-9 June 2016, Valencia, Spain
}

\section{Gender differences in commuting behavior: Women's greater sensitivity}

\author{
Mª Isabel Olmo Sánchez ${ }^{\mathrm{a}}$ Elvira Maeso González ${ }^{\mathrm{b} *}$ \\ ${ }^{a}$ Technical director of the Transportation Management Unit, University of Malaga, Spain \\ ${ }^{b}$ Associate Professor at University of Malaga, Spain \\ Deputy Mayor and delegated councilor of Malaga City Hall Mobility
}

\begin{abstract}
Women's greater sensitivity to changes in their environment is one of the most distinguishing features between both genders. This article raises women's greater sensitivity to the different variables which influence their commuting modal choice. In order to do this, gender gaps detected in the choice of means of transport in commuting trips with respect to the decision factors such as age, education level, driver's license, private transport access; location, household size and net income, are quantified.
\end{abstract}

The results show a greater female sensitivity to the different variables that affect their modal choice, which helps to better understand the different mobility patterns and it is useful for planning measures favoring sustainable mobility policies and equity. 


\section{Introduction}

Proper planning of transport and mobility policies is essential to guarantee people's equality in accessing to goods and services. Thus, the inclusion of a gender perspective in the analysis of mobility aims to avoid the creation of barriers and inequalities for women.

During the last few decades there have been several investigations that have studied the interrelationship between mobility and gender, showing different travel patterns between women and men, motivated largely by the reasons behind these trips (Hanson \&Hanson, 1980; Gordon, Kumar \& Richardson, 1989, Rosenbloom \& Burns, 1993). Overall, women commute more than men, except for those caused by work trips, in which case it is men who perform the highest number of commuting (Olmo \& Maeso, 2013).

Besides from the different reasons for traveling, studies consulted, have found a different modal choice by gender, where going on foot and by public transport is more usual for women (Diaz, 1989; Monzon, Valdes, \& Xue, 2008; Vega \& Roman, 2011; Olmo \& Maeso, 2013).

Despite having a similar role at work and home than ever before, men and women continue to exhibit different travel patterns. (Olmo \& Maeso, 2014; Fan, 2015).

The aim of this paper is to study commuting by analyzing the different demographic, social and economic circumstances that may affect them, including gender perspective in such a way, which would help give a better response from the transportation sector to the new social, economic and environmental challenges of today.

\section{Methodology and data}

This research uses publicly available data from the Social Survey 2011: mobility in the urban regions of Andalusia by the Institute of Statistics and Cartography of Andalusia IECA (2013)

This survey took place in November 2011 although the micro-data was not published until March 2013. The target population was aimed at people aged 16 and over residing in Andalusia. Finally the sample size was 5,767 people performing 17,190 trips in total.

The sample design was made by a three-stage cluster model. The expected relative error for all urban areas was $1.5 \%$ for a statistical confidence level of $95.5 \%$, under the assumption of maximum indetermination $(\mathrm{p}=\mathrm{q}=50 \%)$ and a design effect of 2. The micro-data analysis has been performed using the SPSS statistical package (V15.0).

The descriptive statistical analysis of this data, allows us to reach very interesting conclusions regarding the current gender differences in commuting to work, confirming women's greater sensitivity to changes in their environment has an important influence on their modal choice.

\section{Results}

As we have studied, Spanish women and men continue to exhibit a different travel pattern. In general the largest gender differences are found in travel related to work, where men perform the higher number of trips. On the other hand, the household responsibility trips (shopping, picking up children, medical issues, visits to friends and family etc.) are carried out by women, especially in their forties (Olmo \& Maeso, 2014).

The study of distances and commuting times (Olmo \& Maeso, 2014) shows that the distances traveled by men in working trips $(10.26 \mathrm{~km})$, are much longer than those traveled by women $(6.35 \mathrm{~km})$, while the average travel times spent on these trips are similar. This is a significant fact and supports the thesis of distinct transport used, moreover identified by different authors in different environments.

Several studies (e.g Gordon, Kumar and Richardson 1989; Rosenbloom and Burns, 1993; Olmo and Maeso, 2014) have found the work trips are shorter for women than for men. This result is maintained among different countries (e.g the United States, Canada, The United Kingdom and Spain) in spite of their differences in public transit, car use and in female labour participation rates.

Women try to reduce the distance between home and work and time spent on commuting, while Olmo and Maeso (2014) show that in Spain, although travel distances to work, covered by men, are around $40 \%$ higher than those 
traveled by women, the gender differences in time spent in commuting are lower than those produced when they measure distances, to be almost the same order.

\subsection{Work-trip modal choice}

The analysis we have conducted shows a majority preference towards the use of private vehicles for commuting to work, regardless of gender and age (Table I). However, as we study gender differences in the modal split of transport, we find that women perform a third of their working trips by sustainable transport (on foot, by bicycle or public transport), while men only use it, in just $15 \%$ of their commuting.

We emphasize the fact that, there is although a minority use of public transport in Andalusia, there are large gender differences. In fact, women use public transport for over 13\% of their commutes whereas men use it for less than 3\% of their trips, the gender gap being superior to $50 \%$.

Table 1. Concentration index of trips by mode of transport and gender

\begin{tabular}{lccc}
\hline Mode of Transport & C.I. Men (\%) & C.I. Women (\%) & Gender Gap(\%) \\
\hline Walking/bike & 11.59 & 21.69 & 11.61 \\
Private transport & 85.53 & 64.85 & -32.30 \\
Public transport & 2.88 & 13.45 & 51.86 \\
\hline Total & 100.00 & 100.00 & -19.41 \\
\hline
\end{tabular}

\subsection{Gender differences in the modal choice for work-trips by sociodemographic variables}

This article raises women's greater sensitivity to the different variables that can influence their modal choice in commuting. Therefore, gender gaps identified in our analysis of modal choice with respect to the decision factors such as age, education level, driving license and / or motor vehicle access; location, household size and net income, are quantified.

\subsubsection{Relationship between modal choice, gender and age}

Modal choice analysis by sex and age shows us, that even though women are the majority users of sustainable transport (increasing gender differences significantly from the age of 50), we have observed an increased use of private transport by women aged between 30 and 40, to coincide with their higher level household responsibilities. On the other hand, men's commuting is performed almost exclusively by private vehicle, especially in the younger ages (1629 ), where the percentage of private transport trips is over $90 \%$.

Table 2. Concentration index of trips by mode of transport, gender and age

\begin{tabular}{lccccccccccccc}
\hline Age & \multicolumn{3}{c}{ Young Adults $16-29$} & \multicolumn{3}{c}{ Middle-aged adults 30-39 } & \multicolumn{1}{c}{ Middle-aged adults 40-49 } & Older adults 50-64 \\
\hline Mode of Transport & $\begin{array}{c}\text { C.I. } \\
\text { Men } \\
(\%)\end{array}$ & $\begin{array}{c}\text { C.I. } \\
\text { Women } \\
(\%)\end{array}$ & $\begin{array}{c}\text { Gender } \\
\text { Gap }(\%)\end{array}$ & $\begin{array}{c}\text { C.I. } \\
\text { Men } \\
(\%)\end{array}$ & $\begin{array}{c}\text { C.I. } \\
\text { Women } \\
(\%)\end{array}$ & $\begin{array}{c}\text { Gender } \\
\text { Gap }(\%)\end{array}$ & $\begin{array}{c}\text { C.I. } \\
\text { Men } \\
(\%)\end{array}$ & $\begin{array}{c}\text { C.I. } \\
\text { Women } \\
(\%)\end{array}$ & $\begin{array}{c}\text { Gender } \\
\text { Gap }(\%)\end{array}$ & $\begin{array}{c}\text { C.I. } \\
\text { Men } \\
(\%)\end{array}$ & $\begin{array}{c}\text { C.I. } \\
\text { Women } \\
(\%)\end{array}$ & $\begin{array}{c}\text { Gender } \\
\text { Gap }(\%)\end{array}$ \\
\hline Walking/bike & 7.7 & 21.9 & 42.3 & 9.0 & 17.0 & 17.7 & 13.4 & 20.7 & 0.2 & 13.9 & 29.0 & 4.4 \\
Private transport & 90.7 & 65.4 & -23.0 & 87.7 & 72.6 & -23.0 & 83.9 & 65.0 & -33.0 & 82.7 & 53.7 & -49.3 \\
Public transport & 1.6 & 12.7 & 74.7 & 3.3 & 10.4 & 41.3 & 2.7 & 14.3 & 55.1 & 3.4 & 17.3 & 45.2 \\
\hline Total & 100.0 & 100.0 & -7.0 & 100.0 & 100.0 & -13.9 & 100.0 & 100.0 & -21.2 & 100.0 & 100.0 & -31.3 \\
\hline
\end{tabular}


Public transport is mainly used by women over 50, while, as we can assume, the use of public transport by women aged between 30 and 40 is the minimum. Such unequal modal split by gender and age seems to show how household responsibilities are associated with a greater use of private transport, especially among those which combine working and household responsibility trips.

\subsubsection{Relationship between modal choice, gender and educational level}

The study of commutes regarding educational level shows that gender differences in them, are significantly reduced by increasing the educational level. Thus, gender gaps detected in the group of people with university degrees were $2.7 \%$ for women, compared with the gender gap of $28 \%$ in favor of men, identified in the groups of people with primary and secondary studies.

Table 3. Concentration index of trips by mode of transport, gender and educational level

\begin{tabular}{|c|c|c|c|c|c|c|c|c|c|}
\hline \multirow{2}{*}{$\begin{array}{l}\text { Educational Level } \\
\text { Mode of Transport }\end{array}$} & \multicolumn{3}{|c|}{ Primary } & \multicolumn{3}{|c|}{ Secundary } & \multicolumn{3}{|c|}{ University } \\
\hline & $\begin{array}{c}\text { C.I. Men } \\
(\%)\end{array}$ & $\begin{array}{c}\text { C.I. } \\
\text { Women } \\
(\%)\end{array}$ & $\begin{array}{l}\text { Gender } \\
\operatorname{Gap}(\%)\end{array}$ & $\begin{array}{l}\text { C.I. Men } \\
(\%)\end{array}$ & $\begin{array}{c}\text { C.I. } \\
\text { Women } \\
(\%)\end{array}$ & $\begin{array}{l}\text { Gender } \\
\operatorname{Gap}(\%)\end{array}$ & $\begin{array}{l}\text { C.I. Men } \\
\qquad(\%)\end{array}$ & $\begin{array}{c}\text { C.I. } \\
\text { Women } \\
(\%)\end{array}$ & $\begin{array}{l}\text { Gender } \\
\text { Gap }(\%)\end{array}$ \\
\hline Walking/bike & 12.5 & 24.8 & 6.2 & 9.3 & 20.7 & 10.1 & 17.4 & 22.4 & 15.2 \\
\hline Private transport & 84.0 & 64.7 & -39.1 & 88.1 & 66.1 & -41.5 & 79.1 & 63.1 & -8.6 \\
\hline Public transport & 3.5 & 10.4 & 25.3 & 2.6 & 13.2 & 47.8 & 3.5 & 14.5 & 63.3 \\
\hline Total & 100.0 & 100.0 & -27.6 & 100.0 & 100.0 & -29.0 & 100.0 & 100.0 & 2.7 \\
\hline
\end{tabular}

Regarding people's modal choice, we appreciate that higher levels of education reduces gender gaps in the use of private vehicles. However, the gender differences are increased by women who make greater use of alternative modes, especially public transport. On the other hand, regardless of education level achieved, it is found that men opt for public transport in less than $4 \%$ of their commutes, whereas women use it more when the educational level is higher.

\subsubsection{Relationship between modal choice, gender, driver's license and private transport access}

The availability of driving licence and access to private transport is crucial in the choice of means of transport for everyday commuting, even more so, if they are working trips. In fact, not having a driver's license or not having a private transport access, entails significant restrictions on the mobility of specific groups including women, young people and immigrants (Cebollada and Avellaneda, 2008).

Table 4. Concentration index of trips by mode of transport, gender, driver's license possession and private transport access

\begin{tabular}{lcccccccccccc}
\hline $\begin{array}{c}\text { Driving } \\
\text { license/Private } \\
\text { transport access }\end{array}$ & \multicolumn{1}{c}{ Driving license: Yes } & \multicolumn{1}{c}{ Driving license: No } & Private transport access: Yes & Private transport access: No \\
\hline Mode of Transport & $\begin{array}{c}\text { C.I. } \\
\text { Men } \\
(\%)\end{array}$ & $\begin{array}{c}\text { C.I. } \\
\text { Women } \\
(\%)\end{array}$ & $\begin{array}{c}\text { Gender } \\
\text { Gap }(\%)\end{array}$ & $\begin{array}{c}\text { C.I. } \\
\text { Men } \\
(\%)\end{array}$ & $\begin{array}{c}\text { C.I. } \\
\text { Women } \\
(\%)\end{array}$ & $\begin{array}{c}\text { Gender } \\
\text { Gap }(\%)\end{array}$ & $\begin{array}{c}\text { C.I. } \\
\text { Men } \\
(\%)\end{array}$ & $\begin{array}{c}\text { C.I. } \\
\text { Women } \\
(\%)\end{array}$ & $\begin{array}{c}\text { Gender } \\
\text { Gap }(\%)\end{array}$ & $\begin{array}{c}\text { C.I. } \\
\text { Men } \\
(\%)\end{array}$ & $\begin{array}{c}\text { C.I. } \\
\text { Women } \\
(\%)\end{array}$ & $\begin{array}{c}\text { Gender } \\
\text { Gap }(\%)\end{array}$ \\
\hline Walking/bike & 10.3 & 17.8 & -0.6 & 48.1 & 39.7 & 49.5 & 10.0 & 15.1 & -9.9 & 30.7 & 55.6 & 65.2 \\
Private transp. & 87.3 & 74.1 & -34.5 & 35.9 & 22.5 & 38.4 & 87.5 & 78.0 & -34.7 & 69.3 & 18.2 & -18.6 \\
Public transp. & 2.4 & 8.1 & 31.7 & 16.0 & 37.9 & 78.9 & 2.5 & 6.9 & 20.6 & 0.0 & 26.2 & 100.0 \\
\hline Total & 100.0 & 100.0 & -27.1 & 100.0 & 100.0 & 56.4 & 100.0 & 100.0 & -29.6 & 100.0 & 100.0 & 44.7 \\
\hline
\end{tabular}

In the table above we can see how in Andalusia, there is a high percentage of people, both men and women, who have a driver's license and who have access to private transport. Even so, the possession of both is higher for men. 
Although most people who have a driver's license, choose the private transport for their commute; this choice becomes almost the only option (87.3\%) for men, while women opt for private transport in 3 out of 4 trips to work they perform. Among working people who do not have a driver's license, a large majority of women (77.50\%), who perform their commutes mostly on foot and by public transport is observed. However, although not possessing a driver's license, men's choice of public transport is a minority option accounting for $16.0 \%$ of their commuting.

Finally, private transport is configured as the modal choice for excellence in working trips, and even more when you have a car, especially in the case of men (87.5\% versus $78.0 \%$ of women). Men's public transport choice for commuting remains the pending issue of mobility and transport policies, because as we can see, although men do not have access to a private car, they prefer to go by these means or else walking, to use public transport.

\subsubsection{Relationship between modal choice, gender and household size}

The study we have carried out reveals how the increase in household size has a negative effect on women's commuting to work. Thus, the gender gap of $-10.8 \%$ observed in families with 1 or 2 members increases to $-27.6 \%$ in families of 5 or 6 members.

Table 5. Concentration index of trips by mode of transport, gender and household size

\begin{tabular}{lccccccccc}
\hline \multicolumn{1}{c}{ Household size } & \multicolumn{2}{c}{1 o 2 household members } & \multicolumn{2}{c}{3 o 4 household members } & \multicolumn{2}{c}{5 o 6 household members } \\
\hline \multicolumn{1}{c}{ Mode of Transport } & $\begin{array}{c}\text { C.I. Men } \\
(\%)\end{array}$ & $\begin{array}{c}\text { C.I. } \\
\text { Women } \\
(\%)\end{array}$ & $\begin{array}{c}\text { Gender } \\
\text { Gap }(\%)\end{array}$ & $\begin{array}{c}\text { C.I. Men } \\
(\%)\end{array}$ & $\begin{array}{c}\text { C.I. } \\
\text { Women } \\
(\%)\end{array}$ & $\begin{array}{c}\text { Gender } \\
\text { Gap }(\%)\end{array}$ & $\begin{array}{c}\text { C.I. Men } \\
(\%)\end{array}$ & $\begin{array}{c}\text { C.I. } \\
\text { Women } \\
(\%)\end{array}$ & $\begin{array}{c}\text { Gender } \\
\text { Gap }(\%)\end{array}$ \\
\hline Walking/bike & 14.5 & 21.6 & 9.0 & 10.0 & 21.2 & 16.9 & 11.1 & 25.5 & 13.2 \\
Private transport & 80.0 & 64.2 & -21.4 & 88.3 & 66.5 & -33.4 & 84.2 & 55.6 & -45.5 \\
Public transport & 5.5 & 14.2 & 35.0 & 1.7 & 12.3 & 65.1 & 4.8 & 18.9 & 38.5 \\
\hline Total & 100.0 & 100.0 & -10.8 & 100.0 & 100.0 & -20.2 & 100.0 & 100.0 & -27.6 \\
\hline
\end{tabular}

As for modal choice, it is seen, as in general men use private transport in more than $80 \%$ of their working trips, regardless of their household size, however women's modal choice is much more influenced by their family size. So, in 5 or 6 household members, we can appreciate greater gender differences, as it is reflected by the fact that women use private transport to a lesser extent, opting for the use of alternative means of transport (On foot, bicycle and public transport) in almost half of their working trips.

\subsubsection{Relationship between modal choice, gender and household income}

Considering the number of working trips made by women and men, we can see how the greater household income causes an increased gender gap. Thus, the gap is $-3.3 \%$ in households with net monthly incomes of less than $€ 1,100$, up to the value of $-25.8 \%$ in households with net monthly incomes higher than $€ 2,700$.

Table 6. Concentration index of trips by mode of transport, gender and household income

\begin{tabular}{|c|c|c|c|c|c|c|c|c|c|c|c|c|}
\hline \multirow{2}{*}{$\begin{array}{l}\text { Household income } \\
\text { Mode of Transport }\end{array}$} & \multicolumn{3}{|c|}{$<€ 1,100$} & \multicolumn{3}{|c|}{$€ 1,101-€ 1,800$} & \multicolumn{3}{|c|}{$€ 1,801-€ 2,700$} & \multicolumn{3}{|c|}{$>€ 2,700$} \\
\hline & $\begin{array}{l}\text { C.I. } \\
\text { Men } \\
(\%) \\
\end{array}$ & $\begin{array}{c}\text { C.I. } \\
\text { Women } \\
(\%) \\
\end{array}$ & $\begin{array}{l}\text { Gender } \\
\operatorname{Gap}(\%)\end{array}$ & $\begin{array}{l}\text { C.I. } \\
\text { Men } \\
(\%) \\
\end{array}$ & $\begin{array}{c}\text { C.I. } \\
\text { Women } \\
(\%) \\
\end{array}$ & $\begin{array}{l}\text { Gender } \\
\operatorname{Gap}(\%)\end{array}$ & $\begin{array}{l}\text { C.I. } \\
\text { Men } \\
(\%) \\
\end{array}$ & $\begin{array}{c}\text { C.I. } \\
\text { Women } \\
(\%) \\
\end{array}$ & $\begin{array}{l}\text { Gender } \\
\operatorname{Gap}(\%)\end{array}$ & $\begin{array}{l}\text { C.I. } \\
\text { Men } \\
(\%) \\
\end{array}$ & $\begin{array}{c}\text { C.I. } \\
\text { Women } \\
(\%) \\
\end{array}$ & $\begin{array}{l}\text { Gender } \\
\text { Gap(\%) }\end{array}$ \\
\hline Walking/bike & 14.8 & 25.1 & 22.6 & 8.3 & 21.9 & 26.6 & 11.5 & 22.2 & 12.0 & 11.8 & 16.8 & -8.6 \\
\hline Private transport & 81.8 & 53.2 & -24.3 & 88.7 & 66.0 & -34.7 & 84.6 & 65.0 & -33.0 & 86.3 & 72.1 & -33.9 \\
\hline Public transport & 3.5 & 21.8 & 71.1 & 3.0 & 12.0 & 44.5 & 3.9 & 12.7 & 36.1 & 1.9 & 11.0 & 55.1 \\
\hline Total & 100.0 & 100.0 & -3.3 & 100.0 & 100.0 & -21.1 & 100.0 & 100.0 & -20.8 & 100.0 & 100.0 & -25.8 \\
\hline
\end{tabular}


However the analysis of modal choice offers a different reading, therefore it is strongly influenced by the level of household income. People with low incomes play more the role of pedestrians, cyclists and public transport users. Furthermore in the modal choice of people with the lowest incomes, the largest gender differences in the use of public transport are appreciated, because the gender gap reaches $71.1 \%$, indicating the captivity of public transport to low income working women. By contrast, people with higher incomes tend to be users of private transport. In fact, in our study, $80 \%$ of the commutes of people with family incomes higher than $€ 2,700$ are performed by private car, the gender gap being $-33.9 \%$.

The study of the concentration index of trips by mode of transport according to net family incomes shows again the majority men's choice of private transport (more than $80 \%$ ) regardless of household income. In contrast, women workers from families with very low incomes $(<€ 1,100)$ opt for the use of private vehicles by $53 \%$ of their trips increasing the use of private transport with higher family incomes up to $72 \%$ for net income above $€ 2,700$. Finally, note that regardless of family incomes men choose public transport again in less than $4 \%$ of their commuting.

\subsubsection{Relationship between modal choice, gender and size of town}

The biggest gender differences in commute modal choice are produced in small towns, where gender gap reaches $27.4 \%$ in favour of men decreasing in medium-sized and big cities where gender gaps are of $-19.7 \%$ and $-15.2 \%$, respectively.

Table 7. Concentration index of trips by mode of transport, gender and size of town

\begin{tabular}{lccccccccc}
\hline \multicolumn{1}{c}{ Size of town } & \multicolumn{1}{c}{ Big cities $(>100,000$ population) } & \multicolumn{3}{c}{$\begin{array}{c}\text { Medium size cities }(20,000- \\
100,000 \text { pop })\end{array}$} & Small cities (<20,000 population) \\
\hline \multicolumn{1}{c}{ Mode of Transport } & $\begin{array}{c}\text { C.I. Men } \\
(\%)\end{array}$ & $\begin{array}{c}\text { C.I. } \\
\text { Women } \\
(\%)\end{array}$ & $\begin{array}{c}\text { Gender } \\
\text { Gap }(\%)\end{array}$ & $\begin{array}{c}\text { C.I. Men } \\
(\%)\end{array}$ & $\begin{array}{c}\text { C.I. } \\
\text { Women } \\
(\%)\end{array}$ & $\begin{array}{c}\text { Gender } \\
\text { Gap }(\%)\end{array}$ & $\begin{array}{c}\text { C.I. Men } \\
(\%)\end{array}$ & $\begin{array}{c}\text { C.I. } \\
\text { Women } \\
(\%)\end{array}$ & $\begin{array}{c}\text { Gender } \\
\text { Gap }(\%)\end{array}$ \\
\hline Walking/bike & 14.9 & 24.1 & 8.9 & 12.0 & 20.6 & 7.0 & 5.5 & 17.4 & 28.2 \\
Private transport & 81.4 & 57.4 & -31.6 & 86.4 & 71.7 & -28.5 & 92.0 & 74.9 & -36.6 \\
Public transport & 3.8 & 18.5 & 56.7 & 1.6 & 7.8 & 53.7 & 2.4 & 7.8 & 29.0 \\
\hline Total & 100.0 & 100.0 & -15.2 & 100.0 & 100.0 & -19.7 & 100.0 & 100.0 & -27.4 \\
\hline
\end{tabular}

Analysing the concentration index of trips by mode of transport, we can see how men mostly choose private transport when commuting, being greater than $80 \%$ in large and medium sized cities, and $90 \%$ in small towns. For women, the use of private transport does not reach $60 \%$ in large big cities increasing to $71.7 \%$ and $74.9 \%$ in medium sized and small cities. Thus, although with the decreasing size of cities, women and men opt a greater extent by the use of private vehicles for their trips, it is in small towns where there is greater gender differences witnessed in their use.

Obviously public transport is used to a greater extent in big cities because there is a greater availability as shown by the data analysed. However, despite the greater use of this public transport, it is in these large and medium cities where there is a greater inequality by gender in its use. In fact, gender gap in these cities exceeds $50 \%$, decreasing to $29 \%$ in small cities where the choice of public transport is lesser, due to the lack of necessary infrastructure. Furthermore, it is noteworthy that, regardless of the size of the city, men opt for public transport in less than $4 \%$ of their commutes.

Regarding commuting on foot, although it is the most widely used choice of commuting in large cities, representing only $18.80 \%$ of commutes. It is found that women are the major users especially in small towns reaching the gender gap of $28.2 \%$. 
Therefore, and in light of these results, gender differences in terms of commuting are reduced with the increasing size cities. Still, we found that the size of the city has much more influence in women's modal choice being the men's private transport choice almost independent of the size of the city.

\section{Conclusions}

Significant differences between men and women have been found by this study, when we analyse their commuting to work. It was found that gender differences in commuting to work respond to many aspects of personal and household structure, being the men's modal choice much more resistant to changes in their environment than in the case of women.

The results of this study suggest the existence of a lower mobility in women, who in addition to a fewer number of working trips; perform the distances considerably shorter than men. While it is true, that the time spent in commutes is similar to men. This lower average speed of women's commute is consistent with less use of private vehicles, as well as the different location of the jobs elsewhere.

Regarding the modes of transport used, even if the private vehicle is the overwhelming preference of men and women for commuting to work, catches the attention of how men choose private transport by more than $80 \%$ of all their trips regardless of age, education level, driver's license, private transport access; location, household size and net income.

But women aged 30-39 are the great users of private vehicles in working trips, also coinciding with their largest number of daily trips and less use of public transport. This shows that their busy careers and household responsibilities increase their mobility needs which are currently not covered by public transport.

As for the use of public transport, even when we know women are the main users, we want to highlight the important influence of variables such as education level, net income or household size in their choice.

The results have proven that women over 50 years of age perform less trips that women typically in their reproductive period of 30 to 40 years of age. This fact along with their higher use of private transport in their 40's and the big gender difference noticed in larges families reflect the share of domestic work by women with the same conditions (education level and economic situation) than men.

This leads women to combine their working trips with other numerous intended trips; therefore they are in a position to spend less time, especially coinciding with motherhood which is fundamental for their mobility patterns.

The verification of the greater sensitivity of women's commuting behaviour to changes in variables, such as age, education level, driver's license, private transport access; location, household size and net income, compared with the almost static modal choice of men, points out the necessity on one hand, implement measures such as strategic location of public transport next to schools, supermarkets, car parks, etc. or modified schedules need to be implemented in order to adapt the real necessities of women. Furthermore, investigations need to be carried out in order to discover why men are not taking advantage of the supplied public transport network.

\section{References}

CEBOlladA, A., \& AVELlANEDA, P. (2008). "Equidad social en movilidad: reflexiones en torno a los casos de Barcelona y Lima". Scripta Nova. Revista Electrónica de Geografía y Ciencias Sociales, Universidad de Barcelona, Vol. 12 (270).

DÍAZ, M. (1989). Movilidad femenina en la ciudad. Notas a partir de un caso. Documents d'analisi geográfica, Vol. 14, pp. 219 -239.

FAN, Y. (2015). Household structure and gender differences in travel time: spouse/partner presence, parenthood, and breadwinner status. Transportation, pp. 1-21.

GORDON, P., KUMAR, A, \& RICHARDSON, H. (1989). Gender differences in metropolitan travel behavior. Regional Studies 23(6), pp. 499 510

HANSON, S. \& HANSON, P. (1980). Gender and urban activity patterns in Uppsala, Sweden. Geographical Review 70, pp. 291 - 299.

IECA. (2013). Social Survey 2011: Mobility in the Urban regions of Andalusia. Institute Statistics and Cartography of Andalusia.

MONZÓN, A., VALDÉS, C., \& XUE, G. (2008). La Movilidad en la Comunidad de Madrid. ¿Diferencias según género? Congreso de ingeniería del transporte. Coruña (A). 
OLMO, M., \& MAESO, E. (2013). Diferencias de género en la movilidad en regiones urbanas de Andalucía. Revista Latino-Americana de Geografía e Gênero, Vol. 4, No 2, pp. 13-28.

OLMO, M., \& MAESO, E. (2014). "Travel Patterns, Regarding Different Activities: Work, Studies, Household Responsibilities and Leisure”. Transportation Research Procedia, Vol. 3, 2014, pp.119-128.

ROSENBLOOM, S. \& BURNS, E. (1993). Gender Differences in Commuter Travel in Tucson: Implications for Travel Reduction Programs. Transportation Research Record, 1404, pp. 82 - 90.

VEGA, P., \& ROMAN, M. (2011). Patrones Movilidad Transporte Público Andalucía. Sevilla: Consejería de Obras Públicas y Vivienda. Dirección General de Transportes. 